Anna Dabkowska

DOI: 10.33896/PorJ.2020.4.6

(Uniwersytet Warszawski,

e-mail: anna.a.dabkowska@gmail.com)

ORCID: 0000-0002-8169-8871

\title{
KIEDY NAUKA GRZECZNOŚCI IDZIE W LAS. ROZMOWY POLITYKÓW W MEDIACH
}

Przedmiotem artykułu sa wypowiedzi polityków kierowane w mediach do innych polityków; w sytuacjach, kiedy rozmowa odbywa się w studiu nieraz także do dziennikarzy prowadzacych program. Materiał badawczy obejmuje około 1000 wypowiedzi - zarówno ustnych ( $z$ radia i telewizji), jak i pisemnych (z Twittera). Pochodzą one $z$ lat 2011-2019, czyli z dwóch ostatnich kadencji Sejmu.

Celem artykułu jest opisanie sposobów deprecjonowania przeciwników politycznych za pomoca świadomego przekraczania norm grzeczności. Odpowiem na pytanie, które szczegółowe zasady tradycyjnej polskiej grzeczności łamane są najczęściej.

Od dawna ważnym składnikiem etykiety towarzyskiej była rozmowa. Zasady jej prowadzenia opisywane były przez liczne poradniki dobrego wychowania. Najpierw tłumaczone (zwłaszcza z języka francuskiego), potem - szczególnie w końcu XIX wieku, kiedy rozpoczęła się kodyfikacja zasad polskiej grzeczności - pisane przez autorów polskich.

Przytoczę fragment podręcznika $z$ okresu PRL, kiedy to w związku $z$ awansem zawodowym i społecznym dużych grup dotychczas "grzecznościowo zaniedbanych" zapotrzebowanie na tego rodzaju wydawnictwa było ogromne. Autorka Irena Gumowska w rozdziale Umiejętność prowadzenia rozmowy pisze tak: „Umiejętność ta jest wielką sztuką”. A dalej:

Nikt nie żąda oczywiście ani się nie spodziewa, że goniec będzie mówił tak jak profesor lub przekupka jak aktorka dramatyczna. Każdy jednak człowiek dobrze wychowany i opanowany, zarówno przekupka, jak i uczony, nigdy nie wymyśla innym, nie odzywa się złośliwie czy ordynarnie - nawet w gniewie [podkr. moje - A.D.], choćby nie wiem jak swędział go język [Gumowska 1962, 249].

Według tego kryterium wypowiedzi współczesnych polityków, będące przedmiotem artykułu, należałoby określić jako wypowiedzi ludzi niewychowanych. Ale to byłoby za proste. Czasy się zmieniły. Etykieta towarzyska obowiąuje nadal. Po roku 1989 w Polsce zaczęła obowiązywać 
ponadto międzynarodowa etykieta biznesu. Ale świat mediów zdaje się rządzić innymi zasadami.

Napisała o tym książkę amerykańska socjolingwistka Deborah Tannen. Oto cytat $z$ rozdziału wstępnego:

To nie jest książka o uprzejmości. Słowo „uprzejmość” przywodzi na myś1 powierzchowna, trudną do uchwycenia atmosferę grzeczności, która cienką warstwa, niczym dżem grzankę, okrywa relacje międzyludzkie. Ta książka jest poświęcona wszechobecnej wrogości, która sprawia, że do publicznych rozmów i wszystkiego, co musimy osiągnąć, przystępujemy tak, jakbyśmy ruszali do boju [Tannen 2003, 13].

I dalej:

(...) zdominowała nas cywilizacja kłótni. Cywilizacja kłótni zmusza nas do traktowania świata - i żyjących na nim ludzi - w kategoriach wrogów [podkr. moje - A.D.]. Opiera się ona na założeniu, że przeciwstawienie się komuś lub czemuś jest najlepszym sposobem osiagnięcia celu. Optymalna metoda przedyskutowania kwestii jest zorganizowanie debaty; najdoskonalszym pomysłem na przekazanie informacji jest znalezienie ludzi, którzy wyraża je w krańcowo odmienny sposób, prezentując całkowicie spolaryzowane poglądy. O takich ludziach mówi się, że sa przedstawicielami „obydwu stron” [Tannen 2003, 13].

Analizowane w tym artykule wypowiedzi polityków, będące niejako egzemplifikacją tezy D. Tannen, różnią się od siebie formą - ustną bądź pisemną. W wypadku Twittera inna jest ponadto spójność pisemnych replik dialogowych, które moga być od siebie oddalone w czasie, a to powoduje, że struktura dialogu jest odmienna od struktury dialogu odbywanego twarzą w twarz.

W wypadku dialogów ustnych interlokutorzy widzą się, komunikacja zachodzi synchronicznie, przekazywane treści płyna również z kanałów pozawerbalnych. W wypadku dialogów pisemnych tej możliwości nie ma, więc ewentualne zweryfikowanie intencji nadawcy przez sprawdzenie jego mimiki, gestów czy intonacji jest niemożliwe. Komunikacja pisemna jest asynchroniczna, może się odbywać bez czynnego udziału adresata (nie na każdy tweet kierowany do konkretnego odbiorcy tenże odpowiada).

W jednym i drugim wypadku można mówić o odbiorcy bezpośrednim i pośrednim. Odbiorcy bezpośredni (adresaci) to osoby, do których zgodnie $z$ intencja nadawcy kierowany jest komunikat, pośredni zaś to goście w studiu, słuchacze radiowi, widzowie telewizyjni oraz internauci. Bez względu na typ odbiorcy cel nadawcy jest podobny - wpłynąć na wyborców (to część odbiorców pośrednich), przekazać im swoje przesłanie, a przynajmniej dobrze wypaść w ich oczach. Pożądanym celem nadawców jest również przekonanie do siebie osób dotychczas nieprzekonanych, czyli potencjalnych wahających się wyborców.

W wypadku wypowiedzi pisemnych możliwy jest dłuższy namysł nad ich formą i treścią, choć niejednokrotnie tweety sprawiają wrażenie pi- 
sanych w podobnym stopniu „na goraco” co analogicznie wygłaszane wypowiedzi ustne. Świadczyć o tym moga błędy literowe i inne wynikajace $z$ pośpiechu oraz aktualność tematu - tweety pojawiają się zaraz po danym wydarzeniu.

Po przeanalizowaniu wypowiedzi spełniających założone kryteria wyróżniłam 8 najczęściej spotykanych sposobów deprecjonowania przeciwników politycznych oraz ich działań. Omówię je poniżej, ilustrując przykładami. ${ }^{1}$ Analizę rozpoczynam od wypowiedzi w najmniejszym stopniu naruszających normę grzecznościową, a kończę na wypowiedziach $z$ pogranicza etykiety i etyki mówienia. ${ }^{2}$

\section{FORMA ADRESATYWNA WY ZAMIAST DOTYCHCZAS STOSOWANEJ PAŃSTWO}

Przed rokiem 1989, który jest wyraźna cezura „psucia się” obyczajów grzecznościowych (nazywanego nieraz amerykanizacją obyczajów), powszechna forma zwracania się do audytorium lub publicznie do przedstawiciela (przedstawicieli) jakiejś grupy zawodowej czy społecznej było na przykład Państwo zwróca uwagę.. Forma ta konkurowała wprawdzie $z$ forma mniej elegancka Zwróćcie państwo uwagę.., ale przykładowo w relacjach wykładowców ze studentami były to formy jedyne. Bezdystansowa forma Zwróćcie uwage... zarezerwowana była zasadniczo dla adresatów, do których nadawca zwracał się przez ty, tak jak nauczyciel do uczniów; w wypadku relacji na pan / pani świadczyła o konflikcie.

Obecnie coraz częściej można zauważyć, że politycy, którzy są ze sobą w relacji na pan / pani, zwracaja się do siebie za pomoca formy adresatywnej wy. Zwłaszcza kiedy mają na myśli całą grupę - inna partię, inną orientację polityczną, osoby, które inaczej myślą czy postępują niż nadawcy wypowiedzi. Na przykład:

Ława polityków, TVN24, 29.07.2018

Adrian Zandberg [do Jarosława Sellina]: Panie ministrze, przecież pan świetnie wie, że to nie chodzi o żadne czyszczenie Sądu Najwyższego z postkomunizmu, bo w dziewięćdziesiątym roku 80\% sędziów Sądu Najwyższego - tych umoczonych na przykład w brzydkie sprawy w izbie karnej - zostało z Sąu Najwyższego usuniętych. Tu chodzi o jedna prosta rzecz - wy chcecie po prostu wymontować ostatni bezpiecznik, a chodzi o to, żeby nikt wam nie patrzył na ręce. Bo w tej sprawie, żeby była jasność, proszę państwa [zwraca się do wszystkich gości w studiu], tutaj nie chodzi o to, czy ktoś lubi panią Gersdorf czy ktoś nie lubi pani Gersdorf (...).

1 W wypowiedziach pochodzacych $z$ Twittera zachowuję oryginalna pisownię $\mathrm{i}$ interpunkcję; do wypowiedzi pochodzacych $z$ radia i telewizji nie wprowadzam zmian, swoje uwagi umieszczam w nawiasach kwadratowych.

2 Niejednokrotnie materiał przykładowy zawiera więcej niż jeden ze wskazanych sposobów - w każdym $z$ punktów analizuję jako podstawowy tylko jeden ze sposobów; inne sposoby jedynie ewentualnie wymieniam. 
Adrian Zandberg rozpoczyna swoją wypowiedź od eleganckiej formy adresatywnej panie ministrze, jednak kiedy krytykuje działania PiS-u, zaczyna używać formy wy. Później zaś do wszystkich gości w studiu zwraca się elegancko proszę państwa. Stąd można wywnioskować, że forma $w y$ ma na celu obniżenie rangi przeciwnika politycznego, jest celowym zabiegiem językowym.

Inny przykład $z$ wcześniejszej kadencji Sejmu:

Fakty po Faktach, TVN24, 15.11.2013

Robert Kwiatkowski [do Julii Pitery]: Potykacie się o prawdziwe, tym razem, problemy zwiazzane $z$ nadużyciami władzy waszych polityków, waszych ministrów, prokuratura wam stawia zarzuty, a pani mi wyjeżdża $z$ jakimiś historiami sprzed 10 lat.

Robert Kwiatkowski bezpośrednio do Julii Pitery zwraca się przy użyciu formy adresatywnej pani, z czego wynika, że politycy ci nie sa $\mathrm{w}$ relacji na ty, więc formy potykacie się, waszych polityków, waszych ministrów, wam nie sa tu zasadniczo uprawnione.

\section{ZWRACANIE SIE DO ADRESATA PRZY UŻYCIU NAZWISKA ORAZ MÓWIENIE W PODOBNY SPOSÓB O OSOBACH TRZECICH}

W polszczyźnie ogólnej nie jest przyjęte, żeby do adresata zwracać się po nazwisku. Wyjątkami są regiony, które podlegały wpływowi języka niemieckiego (na przykład Śląsk, Wielkopolska) oraz małe miejscowości, gdzie wszyscy od pokoleń się znaja, i tzw. wsie szlacheckie na wschodzie Polski, gdzie nazwisko ma prestiż rodowy [Marcjanik 2009, 161, 207, 208].

$\mathrm{W}$ poniższym przykładzie nie mamy do czynienia $\mathrm{z}$ takimi wyjątkami:

Krystyna Pawłowicz, 10.08.2019 [Twitter]

Poseł@joannamucha J. MUCHA, NA KOLANA I PRZEPRASZAJ pana posła S. PIOTROWICZA i jego Rodzinę, nienawistnico, szczująca na przyzwoitych ludzi... Zmiana grzywek, zaczepek i układów loków nie zmieni pani podłego charakteru...

Została tu również złamana ogólna norma grzecznościowa okazywania szacunku partnerowi rozmowy. Przede wszystkim manifestuje się to w pouczeniu Joanny Muchy, jak powinna się zachować - nie jest przyjęte w polskiej etykiecie, żeby pouczać dorosłe osoby (dodatkowo wyrażone to zostało krzykiem, który w Internecie manifestuje się wielkimi literami). Można to również dostrzec w skontrastowaniu formy zwracania się do posłanki Joanny Muchy per ty i formy pisania o pośle Stanisławie Piotrowiczu za pomoca formy pan + nazwa funkcji; nie wskazuje to na różną hierarchię tych osób, lecz ma na celu przypisanie niższego statusu J. Musze. Wskazuje na to również użycie wielkich liter w odniesieniu do S. Piotrowicza (Rodzina) i małych w odniesieniu do J. Muchy (nienawistnica). Także użycie obraźliwego epitetu nienawistnico wobec adresatki 
i określenie jej działań jako szczucia na innych przyzwoitych ludzi. I na końcu wpisu - niejako w podsumowaniu - uwaga na temat wyglądu posłanki, znanej z urody i elegancji.

O dorosłych osobach elegancko jest mówić przy użyciu formy pan / / pani + nazwisko (na przykład o sasiadce) albo pan / pani + stanowisko, funkcja czy ranga (na przykład o dyrektorze). Poniżej zamieszczam przykład złamania tej zasady:

Śniadanie $w$ Polsat News, Polsat News, 21.01.2018

Marcin Kierwiński: Teraz mówicie, że będziecie zmieniać regulamin. No bo macie poważny problem. No bo Kaczyński nie może wszystkim sterować ręcznie.

Dominik Tarczyński: Premier Kaczyński.

W polskiej etykiecie nie jest przyjęte, żeby pouczać dorosłe osoby, w związku z tym również wypowiedź Dominika Tarczyńskiego należy uznać za niestosowną.

\section{FORMA LEKCEWAŻĄCA DROGI PANIE, DROGA PANI, KIEROWANA DO OSÓB PEENIĄCYCH FUNKCJE SPOLECZNE LUB ZAWODOWE, DO KTÓRYCH ZWYCZAJOWO ZWRACAMY SIE PANIE POŚLE CZY PANI REDAKTOR}

Forma ta nie tylko zmniejsza dystans, lecz także odwraca hierarchię ważności. Tak może się zwrócić ktoś wyższy w hierarchii zawodowej czy społecznej do kogoś usytuowanego niżej.

Oto przykład:

Gość Radia Zet, Radio Zet, 2.12.2019

Beata Lubecka: Ale jakiś konkret potrzebuję, panie ministrze, no mały premier nie wie, co się dzieje generalnie. A czy w takim razie szef ABW powinien podać się do dymisji? No bo służby sprawdzały chyba Mariana Banasia pod kątem jego kontaktów, w kontekście wynajmu kamienicy?

Łukasz Schreiber: Droga pani redaktor, ja nie wiem, czy w przypadku kandydatów na stanowisko Najwyżej Izby Kontroli są prowadzone tego rodzaju postępowania.

Beata Lubecka przez 3 minuty audycji próbowała dowiedzieć się, jakie plany ma PiS, jeśli Marian Banaś sam nie poda się do dymisji. Łukasz Schreiber unikał jednoznacznej odpowiedzi na te pytania. W końcu, poirytowany natarczywością dziennikarki, zwrócił się do niej za pomocą formy droga pani redaktor. Jest to forma używana doraźnie w sytuacji dialogowego konfliktu. Kiedy rozmówcy mówią o czymś niekontrowersyjnym czy gdy są ze sobą zgodni, wówczas używają form właściwych. 


\section{FORMA LEKCEWAŻACA PROSZE PANA / PANI, KIEROWANA DO OSÓB PEENIĄCYCH WAŻNE FUNKCJE SPOLECZNE LUB ZAWODOWE}

Forma adresatywna prosze pana / pani stosowana jest tylko jako forma inicjujaca kontakt (w relacji na pan / pani), na przykład Proszę pani, po ile te gruszki? $\mathrm{W}$ trakcie rozmowy formy tej $z$ reguły się nie powtarza. Gdy jest powtarzana, może świadczyć o zdenerwowaniu i/lub chęci zdystansowania się od rozmówcy, jego lekceważenia itp.

Na przykład:

Poranna rozmowa w RMF FM, RMF FM, 16.03.2017

Robert Mazurek: Drogi panie Pawle, potrafiłby pan zaśpiewać?

Paweł Kukiz: Co panu zaśpiewać?

RM: A cokolwiek w tej chwili, może coś Wojciecha Młynarskiego.

PK: Nie proszę pana, bo tu nie ma warunków, proszę pana. No ja, proszę pana, potrzebuje jakiegoś natchnienia, jakiejś pięknej istoty, a ja mam przed soba pana, proszę pana.

Tak częste używanie przez Pawła Kukiza formy proszę pana można interpretować jako oznakę jego poirytowania.

W następnym przykładzie forma ta została użyta przez Julię Piterę w celu pouczenia rozmówcy:

Fakty po Faktach, TVN24, 15.11.2013

Julia Pitera: Ja chciałam panu powiedzieć jedną rzecz: macie jednego posła, który jest w sądzie i, jak pan wie, była sprawa kradzieży znaków towarowych. W cywilizowanym świecie - rzecz niedopuszczalna.

Robert Kwiatkowski: No a ma zarzuty prokuratorskie czy nie ma?

JP: Owszem, jest akt oskarżenia w sązie. To jest akt oskarżenia, a nie zarzuty prokuratorskie. Tylko akt oskarżenia, proszę pana.

RK: Już? Skończyła pani?

Robert Kwiatkowski traktuje tu swoją rozmówczynię jak dziecko albo osobę, która nie wie, o czym mówi (ze względu na to, że skrytykowała działanie partii, do której należy rozmówca).

\section{ZWRÓCENIE UWAGI ROZMÓWCY NA NIESTOSOWNOŚĆ JEGO ZACHOWANIA SEOWNEGO}

W polskiej normie grzecznościowej przyjęte jest, że tylko dzieciom można zwracać uwagę na to, że zachowują się niegrzecznie i w ten sposób je wychowywać. Pouczanie dorosłych nie jest dopuszczalne - osoba pouczajaca zyskuje zwykle nieprzychylne miano „przekupki” lub „nauczycielki”. Można to jednak zaobserwować w wypowiedziach polityków: 
Poranna rozmowa w RMF FM, RMF FM, 16.03.2017

Robert Mazurek: Ale nikt nie ma pretensji do pana o to, że pan...

Paweł Kukiz [przerywając mu]: Sekundę. Mam prawo wykupić mieszkanie za 10\% wartości, ponieważ przez 10 lat... Jakie 10? Od 93. roku byłem najemca tego mieszkania, a rodzina moja płaciła 70 lat czynsze za dom, w którym nic od wojny nie zmienili. Więc proszę się ode mnie odp... czepić.

RM [z uśmiechem]: Grzecznie powiedział pan Kukiz.

Inny przykład:

Kropka nad i, TVN24, 10.02.2014

Elżbieta Radziszewska: Niech pan przestanie opowiadać bzdury, że zrobił pan coś dobrego, bo to aż wstyd.

ZZ: Pani się bardzo niekulturalnie...

ER: Aż wstyd.

ZZ: Proszę szanować widzów - pani krzyczy...

ER: Ja nie krzyczę.

Gdy zwrócenie uwagi nie pomaga (w tym wypadku - jak się wydaje - nadrzędnym celem jest uciszenie rozmówczyni, by móc dokończyć przerwaną przez nią wypowiedź), Zbigniew Ziobro sugeruje, że Elżbieta Radziszewska nie szanuje widzów, czyli broni nie swojej osoby, lecz szerszej grupy.

\section{WYTYKANIE ADRESATOWI, ŻE PRZERYWA WYPOWIEDŹ NADAWCY}

$Z$ tego samego powodu - co w punkcie 5. - niestosowne jest zwracanie uwagi rozmówcy, że przerywa on czyjąś wypowiedź. Na przykład:

Fakty po Faktach, TVN24, 15.11.2013

Robert Kwiatkowski: (...) Jest wniosek prokuratury o zdjęcie immunitetu, nie było innego wyjścia i mam nadzieję, że minister Nowak...

Julia Pitera [przerywając mu]: I będzie zdjęty.

RK: ...że minister Nowak... Da mi pani jednak dokończyć?

JP: Oczywiście.

RK: [z ironia] No świetnie, bardzo pani uprzejma.

Samo przerywanie innym, uznawane za nieeleganckie, zostało szeroko omówione w literaturze [m.in. Bloch 2011; Mazurek 2006; Satkiewicz 2000; Sobczak 2006]. Często reakcje na takie zachowanie również cechuje nieuprzejmość, jak w poniższym przykładzie:

Woronicza 17, TVP Info, 30.09.2018

Dobromir Sośnierz: (...) raczej pętla ze wschodu się nad nami zaciska - między Berlinem a Moskwa...

Adrian Zandberg [przerywając mu]: To Korwin tam jeździł do Rosji - z tego, co pamiętam. 
DS: [do Adriana Zandberga]: Ale co pan? Niech pan sobie $z$ Korwinem porozmawia kiedy indziej, a teraz proszę zjeść ciasto, bo ja mówię.

AZ: Niech pan mówi.

DS.: No ale pan mi przerywa.

Niejednokrotnie takie niegrzeczne wypowiedzi sa spowodowane tym, że politycy walczą o czas, który w audycjach jest ograniczony. Chca powiedzieć jak najwięcej, dochodzi do słownych przepychanek. W wypowiedzi Dobromira Sośnierza są elementy grzecznościowe - zwraca się on do rozmówcy za pomoca dystansowej formy pan, dodaje zwrot proszę, ale tylko pozornie jest to grzeczny komunikat. W rzeczywistości polityk ten traktuje swojego rozmówcę $z$ góry, agresywnie reagując na to, że Adrian Zandberg przerwał mu wywód. Uwage zwraca tu ugodowa postawa A. Zandberga, który nie eskaluje konfliktu i na słowa rozmówcy a teraz proszę zjeść ciasto, bo ja mówię odpowiada: Niech pan mówi.

Zdarza się, że polityk - bezradny wobec poczynań interlokutora w studiu - poucza dziennikarza prowadzącego program, jak ten powinien w takiej sytuacji się zachować:

Kawa na ławe, TVN24, 30.12.2018

Michał Wójcik [z irytacją w głosie, do dziennikarza prowadzącego audycję]: Panie redaktorze, pan jest od tego, żeby pilnować porządku w tym programie, no przecież nie może być tak, że pan poseł Szłapka obraża nasze formacje, Zjednoczoną Prawicę, opowiada brednie jakieś tutaj od samego poczatku programu, a kiedy chcę odpowiedzieć, to pan mi przerywa.

Krzysztof Skórzyński: Oddaję panu głos, panie ministrze, proszę bardzo.

\section{ZARZUCANIE ROZMÓWCY NERWOWOŚCI ŚWIADCZAC̨EJ OGÓLNIE O NIEKOMPETENCJI, BARDZIEJ SZCZEGÓLOWO O CHĘCI UKRYCIA CZEGOŚ, O KEAMSTWIE ITP.}

Politycy najczęściej sięgaja po tę technikę erystyczną, żeby speszyć swojego rozmówcę i w ten sposób zyskać nad nim przewagę w studiu. Na przykład:

Kropka nad i, TVN24, 28.11.2013

Stefan Niesiołowski [do Armanda Ryfińskiego, który żądał usunięcia krzyża z Sejmu]: $\mathrm{W}$ imię tego znaku, panie pośle, stawiano opór dyktaturom, przemocy, kłamstwu, nienawiści. Dzięki temu znakowi cywilizacja i kultura w znanym nam kształcie nie uległa, nie przysypał jej śnieg Kołymy ani popiół Oświęcimia. Jeśli ktoś tego nie rozumie, to powinien sobie znaleźć inne zajęcie, a nie politykę.

W powyższym przykładzie zarzuty nie sa skierowane do oponenta bezpośrednio, ale pragmatycznie rzecz ujmując, jest oczywiste, że to wypowiedź skierowana do Armanda Ryfińskiego, a w zwiazku z tym jest to krytyka jego kompetencji jako posła. 


\section{ZARZUCANIE ROZMÓWCY NIEZROZUMIENIA PORUSZANEJ W ROZMOWIE KWESTII, A NAWET WPROST GEUPOTY}

Jest to poważne przekroczenie normy grzecznościowej. Zachowania grzecznościowe wchodzą w zakres etykiety. Etykieta jest częścia starożytnej triady aksjologicznej piękno - dobro - prawda. Zakresy tych trzech wartości się krzyżują.

Przykład z Twittera:

\section{Donald Tusk 1.02.2018}

Kto rozpowszechnia kłamliwe sformułowania o „polskich obozach”, szkodzi dobremu imieniu i interesom Polski. Autorzy ustawy wypromowali to podłe oszczerstwo na cały swiat, skutecznie jak nikt dotąd. A więc, zgodnie $z$ ustawą...

Paweł Kukiz 2.02.2018

Panie Przewodniczący... Powinien pan Bogu dziękować, że nie ma ustawy penalizującej głupotę. Po tym swoim wpisie dostałby pan dożywocie.

Za obraźliwe w stosunku do interlokutora można uznać sugerowanie, że nie jest on w stanie zrozumieć, co zostało powiedziane. Jak w poniższym przykładzie:

Śniadanie $w$ Polsat News, Polsat News, 21.01.2018

Marcin Kierwiński: Senator Kogut został obroniony głosami PiS-u, bo PiS ma...

Dominik Tarczyński [przerywa mu, ale nie słychać, co mówi]

MK: Głosami PiS-u, jeszcze raz, panie pośle, jak pan nie zrozumiał, to jeszcze wolniej.

Następnie Dominik Tarczyński - zapewne w ramach odwetu - w dosadny sposób sugeruje, że jego rozmówca nie potrafi zrozumieć, co ten do niego mówi:

Marcin Kierwiński: Nie kupiliście przez okres tych dwóch lat kompletnie niczego dla polskiej armii. To jest brutalna prawda. (...)

Dominik Tarczyński: Oczywiście pan, jako specjalista od obronności, na pewno wie, jaki procent pieniędzy publicznych, które były przeznaczone w czasie waszych rządów, wydawaliście w MON-ie, a ile my wydaliśmy.

MK: Ale wy właśnie nic nie wydaliście. To jest problem.

DT: Panie pośle, znaczy, wie pan co, ja staram się rozmawiać o danych, ale jak mówię do ściany, przepraszam, panie pośle, to się nie da.

Zachowania omówione w tym punkcie to przykład krzyżowania się etykiety $z$ etyka (dobra $z$ prawda).

Oprócz wskazanych tu sposobów świadomego łamania przez polityków norm grzecznościowych sa też inne, rzadsze, które ze względu na ograniczona objętość tekstu tu się nie znalazły. Szczególnie wart zauważenia jest sposób, który nazywam hipergrzecznością. Stosowany jest nie tylko przez polityków i nie tylko w rozmowach (debatach) publicznych. Polega na stosowaniu przez mówiącego, skonfliktowanego $z$ roz- 
mówca, tzw. obudowy grzecznościowej zdania, na przykład Jeśli moge prosić..., Jeżeli pan pozwoli, to dokończę, Niech pan będzie uprzejmy posłuchać, Zechce pan łaskawie... Tego typu wypowiedzi sprawiają wrażenie salonowo uprzejmych, w istocie jednak - ze względu na funkcję pragmatyczna - maja na celu zdeprecjonowanie rozmówcy, poniżenie go, przedstawienie w krzywym zwierciadle.

Grzeczność ma za zadanie ułatwiać komunikację, sprawiać, że interlokutorzy dobrze czują się w swoim towarzystwie. Za pomoca grzeczności Polacy potwierdzają, że partner rozmowy jest dla nich ważny [Marcjanik 2000, 7-8]. Obrażanie jest tego przeciwieństwem. W wypowiedziach polityków w zebranym materiale można się spotkać ze stwierdzeniem, że interlokutor jest przewrażliwiony, skoro to, co się do niego mówi, go obraża. Może to wynikać $z$ tego, że nadawca takiej wypowiedzi jest świadomy tego, iż złamał zasady, ale nie chce narazić się na miano osoby niewychowanej, nie chce stracić twarzy w Goffmanowskim rozumieniu [Goffman 1981]. W związku $z$ tym kreuje sytuację, $z$ której ma wynikać, że to nie on zrobił coś złego, tylko partner komunikacji niewłaściwie interpretuje jego słowa.

Można zauważyć, że w społeczeństwie jest coraz większe przyzwolenie na niegrzeczne, nieuprzejme zachowania. Być może zmieniają się normy obyczajowe, które obok norm językowych reguluja zachowania grzecznościowe. Coraz więcej zachowań językowych staje się w przekonaniu społecznym zachowaniami stosownymi.

Niegrzeczne, często obraźliwe słowne zachowania polityków w mediach maja niejednokrotnie funkcję ludyczną i sa oczekiwane przez widzów, słuchaczy czy czytelników. Dziennikarze dążą do tego, żeby ich programy były wyraziste, nienudne i przyciagały odbiorców. Podobna metodę stosuja politycy na Twitterze - medium, w którym nie ma dziennikarzy moderujacych dyskusję, ale które pełni w zasadzie te same funkcje, co media tradycyjne.

Opisywane zjawisko jest niepokojące $z$ tego względu, że media - i występujący w nich politycy - kształtuja codzienne zachowania językowe Polaków. W styczniu 2019 roku Rada Języka Polskiego przy Prezydium Polskiej Akademii Nauk wydała oświadczenie wzywające dziennikarzy i polityków do wzmożonej odpowiedzialności za słowo oraz do niepromowania postaw wyrażających się brutalnym językiem. Rok po tym nie widać znaczacych zmian. 


\section{Bibliografia}

J. Bloch, 2011, Bez komentarza, czyli jak unikać odpowiedzi na pytania dziennikarzy, Warszawa.

E. Goffman, 1981, Człowiek $w$ teatrze życia codziennego, tłum. H. Datner-Śpiewak, P. Śpiewak, Warszawa.

I. Gumowska, 1962, ABC dobrego wychowania, Warszawa.

M. Marcjanik, 2009, Mówimy uprzejmie. Poradnik językowego savoir-vivre’u, Warszawa.

M. Marcjanik, 2000, Polska grzeczność językowa, Kielce.

R. Mazurek, 2006, Ja panu nie przeszkadzałem, czyli o języku polityków [w:] M. Marcjanik (red.), Retoryka codzienności. Zwyczaje językowe współczesnych Polaków, Warszawa, s. 276-284.

H. Satkiewicz, 2000, Językowe przejawy agresji $w$ mediach [w:] J. Bralczyk, K. Mosiołek-Kłosińska (red.), Język $w$ mediach masowych, Warszawa, s. 28-33.

B. Sobczak, 2006, Wywiad telewizyjny na żywo. Charakterystyka gatunku, Poznań.

D. Tannen, 2003, Cywilizacja kłótni. Jak powstrzymać amerykańska wojne na słowa, tłum. P. Budkiewicz, Poznań.

\section{When the lesson of politeness has not been learnt. Politicians' talks in the media}

\section{Summary}

The object of this paper is politicians' utterances and statements of the period 2011-2019, which were addressed in the media (the radio, television, and Twitter) to other politicians and journalists. This paper intends to describe 8 most common manners of depreciating political opponents and their actions. The research material under analysis shows that the language used by Polish politicians, no matter which party they are members of, becomes more and more impolite. At times, such verbal behaviours fulfil the ludic function and are desired by the audience, listeners, or readers. However, the described phenomenon is disturbing since the media and the people who appear there form the everyday language behaviours of Poles.

Keywords: linguistic politeness - language of politicians - language in the media.

Trans. Monika Czarnecka 